\title{
Model Pembelajaran Kooperatif Dalam Meningkatkan Minat Belajar Pendidikan Agama Kristen
}

\author{
Yulia Susanti Pingga \\ Sekolah Menengah Atas Swasta Pelita Karya Kefamenanu \\ email: liapingga@gmail.com
}

\begin{abstract}
:
This research intends to examine the use of cooperative learning models in Christian Religious Education (PAK) subjects to increase the learning interest of students of class XI IPS 3 SMAN 1 Kupang. This research uses qualitative descriptive methods. Informants are 26 students and 1 PAK teacher. The results revealed that there was a positive response from learners when learning in the classroom was conveyed using the cooperative learning model. This is indicated by indicators: students feel comfortable and happy to follow learning using the cooperative learning model, there is attention from students when the subject matter is delivered using the cooperative learning model as a support to motivate students to be interested in learning activities, students are so interested in following learning by using the cooperative learning model because they get assignments and opportunities to become leaders (leaders) for students. Friends in the group, students are able to remember the material that has been delivered through the cooperative learning model because in group learning they help each other find the material discussed, students can understand the subject matter delivered through the cooperative learning model, as well as the growing interest in learning students when learning materials are delivered using the cooperative learning model.
\end{abstract}

Keywords: cooperative learning; interest in learning; Christian religious education

\begin{abstract}
Abstrak:
Penelitian ini bermaksud untuk meneliti penggunaan model cooperative learning pada mata pelajaran Pendidikan Agama Kristen (PAK) untuk meningkatkan minat belajar siswa kelas XI IPS 3 SMAN 1 Kupang. Penelitian ini menggunakan metode deskriptif kualitatif. Informan yaitu 26 orang siswa-siswi dan 1 orang guru PAK. Hasil penelitian mengungkapkan bahwa terdapat respon positif dari peserta didik saat pembelajaran di kelas yang di sampaikan dengan menggunakan model cooperative learning. Hal ini ditunjukkan dengan indikator: siswa merasa nyaman dan senang mengikuti pembelajaran dengan menggunakan model cooperative learning, adanya perhatian dari siswa ketika materi pelajaran disampaikan menggunakan model cooperative learning sebagai pendukung untuk memotivasi siswa agar berminat dalam kegiatan pembelajaran, siswa begitu tertarik mengikuti pembelajaran dengan menggunakan model cooperative learning karena mereka mendapat tugas dan kesempatan untuk menjadi ketua (pemimpin) bagi teman-teman dalam kelompok, siswa mampu mengingat materi yang telah disampaikan melalui model cooperative learning karena dalam pembelajaran kelompok mereka saling membantu menemukan materi yang dibahas, siswa dapat memahami materi pelajaran yang disampaikan melalui model cooperative learning, serta bertumbuhnya minat belajar siswa ketika materi pembelajaran disampaikan menggunakan model cooperative learning.
\end{abstract}

Kata Kunci: pembelajaran kooperatif; minat belajar; pendidikan agama Kristen 


\section{Pendahuluan}

Penelitian ini membahas model pembelajaran kooperatif dalam upaya meningkatkan hasil belajar Pendidikan Agama Kristen (PAK) di kelas XI IPS 3 SMAN 1 Kota Kupang. Dalam penggunaan model pembelajaran ini, guru PAK memiliki peran penting dalam mengimplementasikannya. Untuk itu, kompetensi guru PAK dalam mengimplementasikan model pembelajaran kooperatif sangat diperlukan.

Berdasarkan Peraturan Menteri Pendidikan Nasional No. 16 tahun 2007 mengenai Standar Kompetensi Guru menyatakan bahwa guru harus memiliki empat kompetensi kepribadian utama yaitu kompetensi pedagogik, kompetensi kepribadian, kompetensi sosial dan kompetensi profesional. Kompetensi pedagogis adalah guru mampu melakukan tindakan reflektif untuk peningkatan kualitas pembelajaran dilakukan dengan penelitian tindakan kelas. ${ }^{1}$ Kompetensi profesional yaitu mampu mengembangkan keprofesionalisme secara berkelanjut dengan melakukan penelitian tindakan kelas.

Sidjabad dalam bukunya "Mengajar secara Profesionalisme" menyatakan, kualitas kemampuan mengajar yang harus dikembangkan oleh guru dalam konteks pendidikan nasional, kompetensi pedagogis meliputi lima aspek: ${ }^{2}$ Pertama, pemahaman guru terhadap peserta didik secara mendalam, guru harus mempelajari dan memanfaatkan prinsip-prinsip yang dikemukakan dalam ilmu psikologi perkembangan dan psikologi kepribadian. Perbedaan usia peserta didik, tentu berbeda pula tingkat dan fungsi perkembangan kognitif, sosial, moral dan kepribadiannya. Pengelolaan kegiatan belajar mengajar dengan efektif, akan berdampak pada pribadi siswa untuk kesadaran akan pentingnya belajar karena adanya stimulus.

Penyelenggaraan pembelajaran merupakan salah satu tugas utama guru sehingga pembelajaran dapat diartikan sebagai kegiatan yang ditujukan untuk membelajarkan siswa. ${ }^{3}$ Pembelajaran dimaksud agar tercipta kondisi yang memungkinkan terjadinya belajar pada diri siswa. Kompetensi yang diperlukan guru untuk mengajar ialah menentukan model pembelajaran berdasarkan karakteristik peserta didik, tujuan atau kompetensi yang akan dicapai dan berdasarkan sifat materi ajarnya. Pembelajaran merupakan bantuan yang diberikan pendidik agar dapat terjadi proses perolehan ilmu dan pengetahuan, penguasaan kemahiran dan tabiat serta pembentukan sikap dan kepercayaan pada peserta didik. ${ }^{4}$ Dengan kata lain, pembelajaran adalah proses untuk membantu peserta didik dapat belajar dengan baik.

Dalam proses pembelajaran siswa perlu terlibat aktif dan menjadi pusat kegiatan pembelajaran di kelas. Guru dapat memfasilitasi proses ini dengan menggunakan cara-cara yang membuat sebuah informasi menjadi bermakna dan relevan bagi siswa. Untuk itu, guru harus memberi kesempatan kepada siswa untuk

1 Daryanto, Penelitian Tindakan Kelas dan Penelitian Tindakan Sekolah (Yogyakarta: Gava Media, 2011), 1.

2 B. S. Sidjabat, Mengajar secara Profeionalsime (Bandung: Yayasan Kalam Hidup, 2011), 81-83.

3 Dimyati dan Mudjono, Belajar dan Pembelajaran (Jakarta: Rineka Cipta, 2006), 105.

${ }^{4}$ Muhammad Fathurrohman, Model - Model Pembelajaran Inovatif: Alternatif Desain Pembelajaran yang Menyenangkan (Jogjakarta: Ar-Ruzz Media, 2015), 16. 
menemukan atau mengaplikasikan ide-ide mereka sendiri, di samping mengajarkan siswa untuk menyadari dan sadar akan strategi belajar mereka sendiri. ${ }^{5}$

Pembelajaran kooperatif didefinisikan sebagai belajar kelompok atau bekerja sama atau bisa sebagai cara individu mengadakan relasi dan bekerja sama dengan individu lain untuk mencapai tujuan bersama. ${ }^{6}$ Pembelajaran kooperatif merupakan model pembelajaran yang mengutamakan kerja sama di antara siswa untuk mencapai tujuan pembelajaran. Dengan pembelajaran kooperatif siswa tidak hanya mampu dalam memperoleh materi, tetapi juga mampu memberi dampak afektif seperti gotong royong, kepedulian sesama teman, dan lapang dada. Tugas kelompok akan memacu satu sama lain mengintegrasikan pengetahuan-pengetahuan baru dengan pengetahuan yang telah dimilikinya.

Model pembelajaran kooperatif dalam beberapa penelitian memiliki manfaat sebagai berikut: pertama, beberapa hasil penelitian membuktikan bahwa penggunaan model pembelajaran kooperatif dapat meningkatkan prestasi belajar siswa sekaligus dapat meningkatkan kemampuan hubungan sosial, menunbuhkan sikap menerima kekurangan diri dan orang lain serta dapat meningkatkan harga diri. Kedua, model pembelajaran kooperatif dapat merealisasikan kebutuhan siswa dalam belajar berpikir, memecahkan masalah dan mengintegrasikan pengetahuan dengan keterampilan. ${ }^{7}$ Hasil penelitian lainnya mengungkapkan bahwa penerapan model pembelajaran kooperatif dapat meningkatkan keaktifan dan hasil belajar. ${ }^{8}$

Berdasarkan beberapa manfaat penerapan model pembelajaran kooperatif di atas, penulis mencoba menganalisis pemanfaatan model pembelajaran ini dalam mengatasi masalah minat belajar PAK di kelas XI IPS 3 SMAN 1 Kota Kupang. Pengamatan awal penulis menunjukkan bahwa minat belajar siswa kelas XI IPS 3 SMAN 1 Kota Kupang terdapat mata pelajaran PAK masih rendah. Hal ini ditunjukkan dengan kekurangaktifan siswa dalam setiap proses pembelajaran di kelas. Untuk itu, penelitian ini mencoba menganalisis bagaimana penerapan model pembelajaran kooperatif oleh guru PAK di kelas XI IPS 3 SMAN 1 Kota Kupang. Apakah dapat meningkatkan minat belajar siswa terhadap mata pelajaran PAK di kelas. Tujuan dari penelitian ini adalah untuk menganalisis jawaban dari kedua pertanyaan tersebut, yaitu untuk mengetahui apakah penerapan model pembelajaran kooperatif oleh guru PAK dapat meningkatkan minat belajar siswa kelas XI IPS 3 SMAN 1 Kota Kupang.

\section{Metode}

Penelitian ini menggunakan metode kualitatif. Data diperoleh melalui observasi dan wawancara. Wawancara dilakukan kepada 1 orang guru PAK. Observasi merupakan pengamatan terhadap guru PAK dalam mengajar serta respon

${ }^{5}$ Robert E. Slavin, Cooperative Learning: Teori, Riset dan Praktik, Terj. Narulita Yusron (Bandung: Nusa Media, 2009), 9.

${ }^{6}$ Wendy Jollife, Cooperative Learning in The Classroom: Putting it into Practice (California: Paul Chapman Publisihing, 2007), 4.

7 Wina Sanjaya, Strategi Pembelajaran: Berorientasi Standar Proses Pendidikan, (Jakarta: Kencana Prenada Media Group, 2006), 242.

8 Ni L. Gd. Marheni dkk. 
siswa kelas XI IPS 3 yang berjumlah 26 orang selama proses pembelajaran di kelas. Analisis data yang digunakan adalah deskriptif kualitatif, yaitu pengkodean data, verifikasi data, dan penarikan kesimpulan. ${ }^{9}$ Analisis data kualitatif adalah upaya yang dilakukan dengan jalan bekerja dengan data, mengorganisasikan data, memilahmilahnya menjadi satuan yang dapat dikelolah, mencari dan menemukan pola, menemukan apa yang penting dan apa yang dipelajari dan memutuskan apa yang akan diceritakan kepada orang lain. ${ }^{10}$

\section{Hasil dan Pembahasan \\ Model Pembelajaran Kooperatif}

Pembelajaran kooperatif adalah strategi pembelajaran yang melibatkan partisipasi siswa dalam satu kelompok kecil untuk saling berintegrasi. ${ }^{11}$ Sistem belajar yang kooperatif, siswa belajar bekerja sama dengan anggota lainnya. Model ini siswa memiliki dua tanggung jawab, yaitu mereka belajar untuk dirinya sendiri dan membantu sesama anggota kelompok untuk belajar. Siswa belajar bersama dalam sebuah kelompok kecil dan mereka dapat melakukannya seorang diri. ${ }^{12}$ Inti pembelajaran kooperatif adalah konsep synergis yakni energi atau tenaga yang terhimpun melalui kerja sama sebagai salah satu fenomena kehidupan masyarakat. Oleh karena itu dapat dikatakan bahwa model pembelajaran ini melatih peserta didik untuk bekerja sama dalam belajar seperti halnya anggota masyarakat. ${ }^{13}$

Model cooperative learning ini dikembangkan untuk mencapai tiga tujuan pembelajaran penting. Ketiga tujuan pembelajaran tersebut adalah sebagai berikut:14 pertama, Hasil Belajar Akademik. Meskipun pembelajaran kooperatif ini mencakup beragam tujuan sosial serta memperbaiki prestasi siswa atau tugas-tugas akademis penting lainnya. Beberapa penelitian dari cooperative learning, Johnson, Slavin dan Kagan membuktikan bahwa model ini lebih unggul dalam membantu peserta didik dalam memahami konsep-konsep yang sulit dan dapat meningkatkan nilai (prestasi) peserta didik pada belajar akademik. Cooperative learning memberi keuntungan baik pada siswa kelompok bawah maupun kelompok atas yang bekerja sama menyelesaikan tugas-tugas akademik. ${ }^{15}$ Kedua, Penerimaan terhadap perbedaan individu. Model cooperative learning adalah penerimaan secara luas dari orang-orang yang berbeda berdasarkan ras, budaya, kelas sosial, kemampuan dan ketidakmampuannya. Cooperative learning memberi peluang bagi peserta didik dari berbagai latar belakang dan kondisi untuk bekerja dengan saling bergantung pada tugas akademik dan melalui penghargaan kooperatif siswa akan belajar menghargai satu sama lain. ${ }^{16}$ Ketiga, Pengembangan keterampilan sosial. Tujuan ketiga adalah

\footnotetext{
9 Sugiyono.

10 Ibid, 84.

11 Siti Nuurulhayati, Pembelajaran Kooperatif yang Menggairahkan, (Jakarta: Wahana, 2002 ), 29.

12 Wina Sanjaya, Strategi Pembelajaran Berorientasi Standar Proses Pendidikan, 239.

${ }^{13}$ Robbin M. Gillies, et.all, The Teacher's Role in Implementing Cooperative Learning in The Classroom (New York: Springer, 2008), 2.

14 Muhammad Fathurrohman, Model-Model Pembelajaran Inovatif.., 48.

15 Miftahul Huda, Cooperative Learning: Metode, Teknik, Struktur dan Model Penerapan (Yogyakarta: Pustaka Pelajar, 2014), 14.

16 Ibrahim, dkk, Pembelajaran Kooperatif (Surabaya: University Press, 2000), 9.
} 
mengajarkan kepada siswa keterampilan bekerja sama dan kolaborasi. Keterampilan keterampilan sosial penting dimiliki oleh siswa sebagai bekal untuk hidup dalam lingkungan sosialnya. ${ }^{17}$

Pembelajaran kooperatif memiliki unsur-unsur yang saling terkait antara yang satu dengan yang lainnya sebagai berikut: ${ }^{18}$ pertama, Saling Ketergantungan Positif (positive interdependence). Ketergantungan positif ini bukan berarti peserta didik bergantung secara menyeluruh kepada peserta didik lainnya. Jika mereka mengandalkan teman lain tanpa dirinya memberi ataupun menjadi tempat bergantungnya bagi sesamanya, hal itu tidak bisa dinamakan ketergantungan positif. Guru harus menciptakan suasana yang mendorong agar siswa merasa saling membutuhkan. Perasaan saling membutuhkan inilah yang dinamakan positive interdependence. Saling ketergantungan tersebut dapat dicapai melalui ketergantungan tujuan, tugas, bahan atau sumber belajar, peran dan hadiah.

Kedua, Akuntabilitas Individual (individual accountability). Cooperative learning menuntut adanya akuntabilitas individual yang mengukur penguasaan bahan belajar tiap kelompok, dan diberi balikan (umpan balik) tentang prestasi belajar anggotaanggotanya sehingga mereka saling mengetahui rekan yang memerlukan bantuan. Berbeda dengan kelompok tradisional, akuntabilitas individual sering diabaikan sehingga tugas-tugas sering dikerjakan oleh sebagian angggota. Cooperative learning, siswa harus bertanggung jawab terhadap tugas yang diemban masing-masing anggota.

Ketiga, Interaksi Promotif (promotive interaction). Interaksi promotif menuntut semua anggota dalam kelompok belajar dapat saling tatap muka. Mereka dapat berdialog tidak hanya dengan guru tetapi juga bersama dengan teman. Interaksi semacam itu memungkinkan peserta didik menjadi sumber belajar bagi sesamanya. Hal ini diperlukan karena mereka sering merasa lebih mudah belajar dari sesamanya dibandingkan dari guru.

Keempat, Keterampilan Interpersonal dan Kelompok Kecil (interpersonal and small group skill). ${ }^{19}$ Unsur keempat dari cooperative learning adalah dibekali berbagai interpersonal and small group skill yakni kepemimpinan (leadership), membuat keputusan (decision making), membangun kepercayaan (trust building), kemampuan berkomunikasi dan keterampilan manajemen konflik (management conflict skill). Keterampilan interpersonal lain seperti: tenggang rasa, sikap sopan kepada teman, mengkritik ide, berani mempertahankan pikiran logis, tidak mendominasi yang lain, mandiri dan berbagai sifat lain yang bermanfaat dalam menjalin hubungan antarpribadi tidak hanya diasumsikan tetapi secara sengaja diajarkan.

Kelima, Proses Kelompok (group processing). Proses ini terjadi ketika tiap anggota kelompok mengevaluasi sejauhmana mereka berintegrasi secara efektif untuk mencapai tujuan bersama. Kelompok perlu membahas perilaku anggota yang kooperatif dan tidak kooperatif serta membuat keputusan perilaku mana yang harus

${ }_{17}$ Spencer Kagan \& Miguel Kagan, Kagan Cooperative Leraning (San Clementer: Kagan Publishing, 2009), 11.3. Isjoni, Pembelajaran Kooperatif (Yogyakarta: Pustaka Pelajar, 2009).

18 Anita Lie, Cooperative Learning: Mempraktekkan Cooprative Learning di Ruang Kelas, 31. Trianto, Mendesain Model., 60.

${ }^{19}$ Johson \& Johson, Cooperative in The Classroom..., 34. 
diubah atau dipertahankan. Pemrosesan kelompok ini bisa berlangsung dalam group kecil atau group besar.

Terdapat lima prinsip dasar cooperative learning, seperti dijelaskan dibawah ini:20 (1) Prinsip ketergantungan positif (positive interdependence) yaitu dalam cooperative learning, keberhasilan dalam penyelesaian tugas tergantung pada usaha yang dilakukan oleh kelompok tersebut. Keberhasilan kinerja kelompok ditentukan oleh kinerja masing-masing anggota kelompok. Semua anggota dalam kelompok akan merasa saling ketergantungan. Untuk terciptanya kelompok kerja yang efektif, setiap anggota kelompok masing-masing perlu membagi tugas sesuai dengan tujuan kelompoknya. Tugas tersebut tentu saja disesuaikan dengan kemampuan setiap anggota kelompok. Inilah hakekat ketergantungan positif artinya tugas kelompok tidak mungkin bisa diselesaikan manakala ada anggota yang tak bisa menyelesaikan tugasnya dan semua ini memerlukan kerja sama yang baik dari masing-masing anggota kelompok. Anggota kelompok yang mempunyai kemampuan lebih, diharapkan mau dan mampu membantu temannya untuk menyelesaikan tugasnya. (2) Tanggung jawab perseorangan (indivudual accountability) yaitu keberhasilan kelompok sangat tergantung dari masing-masing anggota kelompoknya. Setiap anggota kelompok mempunyai tugas dan tanggung jawab yang harus dikerjakan dalam kelompok tersebut. (3) Interaksi tatap muka (face to face promotion interaction) yaitu memberikan kesempatan yang luas kepada setiap anggota kelompok untuk bertatap muka melakukan interaksi dan diskusi untuk saling memberi dan menerima informasi dari anggota kelompok lain. Pembelajaran kooperatif memberi ruang dan kesempatan yang luas kepada setiap anggota kelompok untuk bertatap muka saling memberikan informasi dan membelajarkan. Interaksi tatap muka akan memberikan pengalaman yang berharga kepada setiap anggota kelompok untuk bekerja sama, menghargai setiap perbedaan, memanfaatkan kelebihan masing-masing anggota dan mengisi kekurangan masing-masing. Kelompok belajar kooperatif dibentuk secara heterogen, yang berasal dari budaya, latar belakang sosial dan kemampuan akademik yang berbeda. Perbedaan semacam ini akan menjadi modal utama dalam proses saling memperkaya antara anggota kelompok. ${ }^{21}$ (4) Partisipasi dan komunikasi (participation communication) yaitu melatih siswa untuk dapat berpartisipasi aktif dan berkomunikasi dalam kegiatan pembelajaran. Kemampuan ini sangat penting sebagai bekal mereka dalam kehidupan di masyarakat kelak. Sebelum melakukan kooperatif, guru perlu membekali siswa dengan kemampuan berkomunikasi. Tidak setiap siswa mempunyai kemampuan berkomunikasi, misalnya kemampuan mendengarkan dan kemampuan berbicara, padahal keberhasilan kelompok ditentukan oleh partisipasi setiap anggotanya.

Keterampilan berkomunikasi memang memerlukan waktu. Siswa tak mungkin dapat menguasainya dalam waktu sekejap. Guru perlu terus melatih dan melatih, sampai pada akhirnya setiap siswa memiliki kemampuan untuk menjadi komunikator yang baik. $^{22}$ (5) Evaluasi proses kelompok yaitu menjadwalkan waktu khusus bagi

20 Rusman, Model-Model Pembelajaran Mengembangkan Profesionalisme Guru., 212.

21 Wina Sanjaya, Strategi Pembelajaran Berorientasi Standar Proses Pendidikan, 244.

22 Ibid, 245. 
kelompok untuk mengevaluasi proses kerja kelompok dan hasil kerja sama mereka agar selanjutnya bisa bekerja sama dengan lebih efektif.

Langkah-langkah cooperative learning pada prinsipnya terdiri atas empat tahap yaitu:23 pertama, Penjelasan Materi. Tahap penjelasan diartikan sebagai proses penyampaian pokok-pokok materi pembelajaran sebelum siswa belajar dalam kelompok. Tujuan dalam tahap ini adalah pemahaman siswa terhadap pokok materi pelajaran. Guru pada tahap ini memberikan gambaran umum tentang materi pelajaran yang harus dikuasai yang selanjutnya siswa akan memperdalam materi dalam pembelajaran kelompok (tim). Guru pada tahap ini dapat menggunakan metode ceremah, curah pendapat dan Tanya jawab bahkan kalau perlu guru dapat mengggunakan domonstrasi. Guru juga dapat menggunakan berbagai media pembelajaran agar proses penyampaian dapat lebih menarik siswa.

Kedua, Belajar dalam Kelompok. Setelah guru menjelaskan gambaran umum tentang pokok-pokok materi pelajaran, selanjutnya siswa diminta untuk belajar pada kelompoknya masing-masing yang telah dibentuk sebelumnya. Manurut Anita Lie, pengelompoknya dalam model cooperative learning bersifat heterogen, artinya kelompok dibentuk berdasarkan perbedaan-perbedaan setiap anggotanya, baik perbedaan gender, latar belakang agama, sosial-ekonomi dan etnis serta perbedaan kemampuan akademis. Kemampuan dalam hal akademis, kelompok pembelajaran biasanya terdiri dari satu orang berkemampuan akademis tinggi, dua orang dengan kemampuan sedang dan satu lainnya dari kelompok kemampuan akademis kurang. Lie menjelaskan beberapa alasan lebih disukainya pengelompokan heterogen. Pertama, kelompok heterogen memberikan kesempatan untuk saling mengajar (peer tutoring) dan saling mendukung. Kedua, kelompok ini meningkatkan relasi dan interaksi antara ras, agama, etnis dan gender. ${ }^{24}$ Terakhir, kelompok heterogen memudahkan pengelolaan kelas karena dengan adanya satu orang yang berkemampuan akademis tinggi, guru mendapatkan satu asisten untuk setiap orang. Melalui pembelajaran dalam tim siswa didorong untuk melakukan tukar-menukar (sharing) informasi dan pendapat, mendiskusikan permasalahan secara bersama, membandingkan jawaban mereka dan mengoreksi hal-hal yang kurang tepat.

Ketiga, Penilaian. Penilaian dalam model cooperative learning bisa dilakukan dengan tes atau kuis. Tes atau kuis dilakukan baik secara individual maupun secara kelompok. Tes individual nantinya akan memberikan informasi kemampuan setiap siswa dan tes kelompok akan memberikan informasi kamampuan setiap kelompok. Hasil akhir setiap siswa adalah penggabungan keduanya dan dibagi dua. Nilai setiap kelompok memiliki nilai sama dalam kelompoknya. Hal ini disebabkan nilai kelompok adalah nilai bersama dalam kelompoknya yang merupakan hasil kerja sama setiap anggota kelompok.

Keempat, Pengakuan Tim. Pengakuan tim (team recognition) adalah penetapan tim yang dianggap paling menonjol atau tim paling berprestasi untuk kemudian diberikan penghargaan atau hadiah. Pengakuan dan pemberian penghargaan tersebut diharapkan dapat memotivasi tim untuk terus berprestasi dan juga membangkitkan motivasi tim lain untuk lebih mampu meningkatkan prestasi mareka.

\footnotetext{
23 Ibid.

24 Ibid.
} 


\section{Minat Belajar}

Minat besar sekali pengaruhnya terhadap kegiatan seseorang sebab dengan minat ia akan melakukan sesuatu yang diminatinya. Sebaliknya tanpa minat seseorang tidak mungkin melakukan sesuatu. ${ }^{25}$ Ada berbagai cara yang dapat dilakukan guru untuk membangkitkan minat siswa adalah sebagai berikut: ${ }^{26}$ (a) Membandingkan adanya suatu kebutuhan pada siswa, sehingga dia rela belajar tanpa paksaan. (b) Menghubungkan bahan pelajaran yang diberikan dengan persoalan pengalaman yang dimiliki siswa, sehingga siswa mudah menerima bahan pelajaran. (c) Memberikan kesempatan kepada siswa untuk mendapatkan hasil belajar yang baik dengan cara menyediakan lingkungan belajar yang kreatif dan kondusif. (d) Menggunakan berbagai macam bentuk dan teknik mengajar dalam konteks perbedaan individu siswa.

\section{Hasil Penelitian}

Hasil penelitian mencakup hasil wawancara dan observasi. Wawancara kepada guru PAK mencakup lima pertanyataan. Pertanyaan tersebut berkaitan dengan penggunaan metode pembelajaran, penggunaan model pembelajaran, kendala yang dihadapi dalam menggunakan model pembelajaran, cara mengatasi kendala penggunaan model pembelajaran kooperatif.

\section{Model Pembelajaran}

Istilah model dalam perspektif yang dangkal hampir sama dengan strategi. Jadi, model pembelajaran hampir sama dengan strategi pembelajaran. Menurut Sagala, istilah model dapat dipahami sebagai suatu kerangka konseptual yang digunakan sebagai pedoman dalam melakukan suatu kegiatan. ${ }^{27}$ Model dapat dipahami juga sebagai: 1) suatu tipe atau desain. 2) suatu deskripsi atau analogi yang dipergunakan untuk membantu proses visualisasi sesuatu yang tidak dapat dengan langsung diamati. 3) suatu sistem asumsi-asumsi, data-data dan inferensi-inferensi yang digunakan menggambarkan secara sistematis suatu objek atau peristiwa. 4) suatu desain yang disederhanakan dari suatu sistem kerja, suatu terjemahan realitas yang disederhanakan. 5) suatu deskripsi dari suatu sistem yang mungkin atau imajiner. 6) penyajian yang diperkecil agar dapat menjelaskan dan menunjukan sifat bentuk aslinya. ${ }^{28}$ Model dirancang untuk mewakili realitas yang sesungguhnya walaupun model itu sendiri bukanlah realitas dari dunia yang sebenarnya. ${ }^{29}$ Jadi, model pembelajaran adalah kerangka atau susunan konseptual yang digunakan sebagai pedoman dalam melakukan kegiatan pembelajaran.

25 Pusat Bahasa Departemen Pendidikan Nasional. Kamus Besar Bahasa Indonesia. (Jakarta: Balai Pustaka: 2007), 744.

${ }^{26}$ Ibrahim, dkk, Pembelajaran Kooperatif (Surabaya: University Press, 2000), 9.

27 Syaiful Sagala, Supervisi Pembelajaran Dalam Profesi Pendidikan: Membantu Mengatasi Kesulitan Guru Memberikan Layanan Belajar yang Bermutu (Bandung: Alfabeta, 2010), 62.

28 Komaruddin, Kamus Istilah Karya Tulis Ilmiah (Jakarta: Bumi Aksara, 2000), 152.

29 Syaiful Sagala, Konsep dan Makna Pembelajaran: Untuk membantu Memecahkan Problematika Belajar Mengajar, 176. 
Pandangan yang sama dikemukakan oleh Eggen dan Kauchak, dalam Trianto, bahwa model pembelajaran memberikan kerangka dan arah bagi guru untuk melakukan pembelajaran. ${ }^{30}$ Menurut Joyce dan Weil mendefinisikan model pembelajaran sebagai suatu perencanaan atau suatu pola yang digunakan sebagai pedoman dalam melaksanakan pembelajaran di kelas untuk menentukan perangkatperangkat pembelajaran. ${ }^{31}$ Model pembelajaran merupakan suatu pendekatan pembelajaran yang menyeluruh. Sedangkan menurut Arends, model pembelajaran adalah suatu rencana atau pola yang disiapkan untuk membantu peserta didik mempelajari secara lebih spesifik berbagai ilmu pengetahuan, sikap dan keterampilan. ${ }^{32}$ Jadi yang dinamakan model pembelajaran adalah suatu rencana yang berpijak dari teori psikologi yang digunakan sebagai pedoman bagi guru dalam merencanakan dan melaksanakan kegiatan belajar mengajar.

Model pembelajaran adalah bentuk pembelajaran yang menggambarkan kegiatan dari awal sampai akhir yang disajikan secara khas oleh guru. Penggunaan model pembelajaran haruslah sesuai dengan materi pelajaran supaya dapat menciptakan lingkungan belajar yang menjadikan peserta didik belajar. Melalui model pembelajaran terdapat strategi pencapaian kompetensi peserta didik dengan pendekatan, metode dan teknik pembelajaran tertentu.

Berdasarkan pandangan di atas dapat disimpulkan bahwa model pembelajaran sebagai pedoman bagi perancang pengajar dan para guru dalam melaksanakan pembelajaran. Untuk memilih model ini sangat dipengaruhi oleh sifat dari materi yang akan diajarkan dan juga dipengaruhi oleh tujuan yang akan dicapai dalam pengajaran tersebut serta tingkat kemampuan peserta didik. ${ }^{33}$

\section{Ciri-Ciri Model Pembelajaran}

Menurut Kardi, Nur dan Trianto, istilah model pembelajaran mempunyai makna yang lebih luas daripada strategi, metode atau prosedur. Model pengajaran mempunyai empat ciri khusus yang tidak dimiliki oleh strategi, metode atau prosedur. ${ }^{34}$

Ciri-ciri khusus model pembelajaran adalah: ${ }^{35}$ pertama, rasional teoretis logis yang disusun oleh para pencipta atau pengembangnya. Model pembelajaran mempunyai teori berfikir yang masuk akal. Maksudnya para pencipta atau pengembang membuat teori dengan mempertimbangkan teorinya dengan kenyataan sebenarnya serta tidak secara fiktif dalam menciptakan dan mengembangkannya. Kedua, landasan pemikiran tentang apa dan bagaimana siswa belajar (tujuan pembelajaran yang akan dicapai). Model pembelajaran mempunyai tujuan yang jelas tentang apa yang akan dicapai, termasuk di dalamnya apa dan bagaimana siswa belajar dengan baik serta cara memecahkan suatu masalah pembelajaran. Ketiga,

30 Trianto, Mendesain Model Progresif: Konsep, Landasan dan Implementasinya pada Kurikulum Tingkat Satuan Pendidikan (Jakarta: Kencana Prenada Media, 2009), 22.

31 Bruce Joyce and Marsha Weil, Models of Teaching (Boston: Allyn and Bacon, 2009$), 7$.

32 Ricards I. Arends, Learning ti Teach..., 24.

${ }_{33}$ Trianto, Mendesain Model Progresif: Konsep, Landasan dan Implementasinya pada Kurikulum Tingkat Satuan Pendidikan, 53.

${ }^{34} \mathrm{Ibid}, 142$.

35 Ricards I. Arends, Learning to Teach, 6-7. 
tingkah laku mengajar yang diperlukan agar model tersebut dapat dilaksanakan dengan berhasil. Model pembelajaran mempunyai tingkah laku mengajar yang diperlukan sehingga apa yang menjadi cita-cita mengajar selama ini dapat berhasil dalam pelaksanaannya. Keempat, lingkungan belajar yang diperlukan agar tujuan pembelajaran itu dapat tercapai. Model pembelajaran mempunyai lingkungan belajar yang kondusif serta nyaman, sehingga suasana belajar dapat menjadi salah satu aspek penunjang apa yang selama ini menjadi tujuan pembelajaran.

Ciri-ciri di atas tampaknya mendeskripsikan bahwa suatu model pembelajaran ditentukan berdasarkan pertimbangan ilmiah dan menggunakan prosedur yang sistematik. Pada Akhirnya setiap model pembelajaran memerlukan sistem pengelolaan dan lingkungan belajar yang berbeda. Model pembelajaran dalam perkembangannya berkembang menjadi banyak. Terdapat model pembelajaran yang kurang baik dipakai dan diterapkan, namun ada model pembelajaran yang baik untuk diterapkan. Ciri-ciri model pembelajaran yang baik adalah sebagai berikut: ${ }^{36}$ pertama, adanya keterlibatan intelektual-emosional peserta didik melalui kegiatan mengalami, menganalisis, berbuat dan pembentukan sikap. Kedua, adanya keikutsertaan peserta didik secara aktif dan kreatif selama pelaksanaan model pembelajaran. Ketiga, guru bertindak sebagai fasilitator, koordinator, mediator yaitu perantara, pemisah antara mereka yang berselisih atau bertengkar dan motivator kegiatan belajar peserta didik. Keempat, penggunaan berbagai metode, alat dan media pembelajaran. Apabila model pembelajaran memenuhi ciri-ciri yang penulis sebutkan, model pembelajaran tersebut dikatakan model pembelajaran yang baik. Namun sebaliknya apabila tidak memenuhi ciri-ciri yang penulis sebutkan maka dikatakan model pembelajaran yang jelak.

\section{Model Cooperative Learning}

Konsep Dasar Cooperative Learning

Cooperative learning atau pembelajaran kooperatif adalah salah satu bentuk pembelajaran yang berdasarkan paham konstruktivisme. Secara filosofis, belajar menurut teori konstruktivisme adalah membangun pengetahuan sedikit demi sedikit yang kemudian hasilnya diperluas melalui konteks yang terbatas dan tidak sekonyong-konyong. Pengetahuan bukanlah seperangkat fakta-fakta, konsep-konsep atau kaidah yang siap diambil atau diingat. Manusia harus mengkontruksi pengetahuan itu dan memberi makna melalui pengalaman nyata. ${ }^{37}$ Cooperative learning merupakan model pembelajaran yang mengutamakan kerja sama di antara siswa untuk mencapai tujuan pembelajaran.

Slavin menyatakan bahwa dalam proses pembelajaran siswa harus terlibat aktif dan menjadi pusat kegiatan pembelajaran di kelas. Guru dapat memfasilitasi proses ini dengan mengajar menggunakan cara-cara yang membuat sebuah informasi menjadi bermakna dan relevan bagi siswa. Guru harus memberi kesempatan kepada siswa untuk menemukan atau mengaplikasikan ide-ide mereka sendiri, di samping mengajarkan siswa untuk menyadari dan sadar akan strategi belajar mereka sendiri. ${ }^{38}$

36 Muhammad Fathurrohman, Model-model Pembelajaran, 31.

37 Bahruddin dan Esa Nur Wahyuni, Teori Belajar \& Pembelajaran (Jogjakarta: Ar-Ruzz Media, 2007).

\footnotetext{
38 Robert E. Slavin, Cooperative Learning: Teori \& Pembelajaran, 9.
} 
Pembelajaran ini akan tercipta sebuah interaksi yang lebih luas yaitu interaksi dan komunikasi yang dilakukan antara guru dengan siswa, siswa dengan siswa dan siswa dengan guru (multi way traffic comunication). Pembelajaran kooperatif adalah strategi pembelajaran yang melibatkan partisipasi siswa dalam satu kelompok kecil untuk saling berintegrasi. ${ }^{39}$ Sistem belajar yang kooperatif, siswa belajar bekerja sama dengan anggota lainnya. Model ini siswa memiliki dua tanggung jawab, yaitu mereka belajar untuk dirinya sendiri dan membantu sesama anggota kelompok untuk belajar. Siswa belajar bersama dalam sebuah kelompok kecil dan mereka dapat melakukannya seorang diri. ${ }^{40}$

J. Johson dan Johson menerangkan hasil penelitian bahwa belajar kooperatif akan mendorong siswa belajar lebih banyak materi pelajaran, merasa lebih nyaman dan termotivasi lebih banyak materi pelajaran, merasa lebih nyaman dan termotivasi untuk belajar, mencapai hasil belajar yang tinggi, memiliki kemampuan yang baik untuk berpikir secara kritis, memiliki sikap positif terhadap objek studi, menunjukan kemampuan yang lebih baik dalam aktivitas kerja sama, memiliki aspek psikologis yang lebih sehat dan mampu menerima perbedaan yang ada di antara teman satu kelompok. ${ }^{41}$

Inti pembelajaran kooperatif adalah konsep synergis yakni energi atau tenaga yang terhimpun melalui kerja sama sebagai salah satu fenomena kehidupan masyarakat. Oleh karena itu dapat dikatakan bahwa model pembelajaran ini melatih peserta didik untuk bekerja sama dalam belajar seperti halnya anggota masyarakat. ${ }^{42}$ Strategi pembelajaran seperti ini penerapannya beranjak dari konsep Dewey bahwa Classroom should mirror the large society and be a laboratory for real life learning. ${ }^{43}$ Artinya kelas seharusnya mencerminkan keadaan masyarakat luas dan menjadi laboratorium untuk belajar kehidupan nyata.

Berdasarkan pandangan di atas, maka dapat disimpulkan bahwa model cooperative learning dirancang untuk memanfaatkan fenomena kerja sama atau gotong royong dalam pembelajaran yang menekankan terbentuknya hubungan antara siswa yang satu dengan yang lainnya, terbentuknya sikap dan perilaku yang demokratis serta tumbuhnya produktivitas kegiatan belajar siswa. Cooperative learning dapat digunakan untuk melatih kompetensi sikap, sosial dan kepekaan terhadap orang lain serta kolaborasi dengan orang lain.

Jika ditinjau lebih dalam terdapat beberapa alasan penting mengapa cooperative learning ini perlu diterapkan di sekolah-sekolah atau madrasah-madrasah adalah karena seiring dengan proses globalisasi, terjadi juga transformasi pada madrasahmadrasah untuk lebih menyiapkan peserta didik dengan keterampilan-keterampilan hidup (life skill) bermasyarakat dan untuk meningkatkan prestasi belajar peserta

39 Siti Nuurulhayati, Pembelajaran Kooperatif yang Menggairahkan, (Jakarta: Wahana, 2002 ), 29.

40 Wina Sanjaya, Strategi Pembelajaran Berorientasi Standar Proses Pendidikan, 239.

41 D.W. Johson \& R.T. Johson, Cooperation in The Classroom (USA: Interaction Book Company, 1998).

42 Robbin M. Gillies, et.all, The Teacher's Role in Implementing Cooperative Learning in The Classroom (New York: Springer, 2008), 2.

${ }^{43}$ Gerald L Gutek, Historical and Philosophical Foundations of Education: A Biographical Introduction (Upper Saddle River, NJ: Person Education Inc, 2000). 
didiknya. Dengan demikian mereka mampu berpartisipasi aktif dalam dunia yang cepat berubah dan berkembang pesat.

Berikut adalah penjelasan lebih rinci tentang alasan-alasan tersebut: ${ }^{44}$ pertama, transformasi sosial. Transformasi sosial secara sederhana dapat dilihat dalam perubahan struktur keluarga. Semakin banyak anak yang dibesarkan dalam keluarga inti tanpa kehadiran dan pengasuhan penuh orangtua. Parahnya, seorang anak bisa meluangkan waktunya lebih banyak di depan televisi, bermain games dan play station daripada berbicara dengan ayah atau ibu mereka. Dengan kata lain, saat mata mereka terpaku pada layar kaca, hilanglah kesempatan untuk mengembangkan interaksi sosial dan kemampuan berkomunikasi anak. Pendidikan diperlukan karena pendidikan tidak lagi hanya memperhatikan perkembangan kognitif saja, tetapi juga sisi moral dan sosialnya. Pendidikan harus memberikan banyak kesempatan untuk belajar berinteraksi dan bekerja sama dengan sesama.

Kedua, tranformasi ekonomi. Interdependence menjadi ciri transformasi ekonomi. Kemampuan individu akan menjadi hal yang sia-sia ketika tidak diimbangi dengan kemampuan bekerja sama. Kemampuan bekerja sama ini akan menjadi modal penting untuk mencapai tujuan dan keberhasilan suatu usaha. Pendidik sebagai guru harus bertanggung jawab dan merasa terpanggil untuk mempersiapkan anak didiknya agar bisa berkomunikasi dan bekerja sama dalam berbagai macam situasi sosial.

Ketiga, transformasi demografis. Transformasi demografis dicirikan dengan adanya urbanisasi. Kompetisi dan eksploitasi adalah bentuk konsekuensi hidup dalam bermasyarakat urban. Realitas menunjukan bahwa urbanisasi memegang peranan dalam penciptaan homo homini lupus. Sekolah seharusnya bisa berbuat lebih banyak dalam mengubah arah evolusi nilai sosial. Sebagai rumah kedua, sekolah merupakan tempat untuk menanamkan sikap-sikap kooperatif dan mengajarkan caracara bekerja sama dengan maksud untuk membentuk siswa menjadi homo homini socius.

Tujuan cooperative learning adalah menciptakan situasi ketika keberhasilan individu ditentukan atau dipengaruhi oleh keberhasilan kelompoknya. Hal ini berbeda dengan tujuan pembelajaran konvensional yang menerapkan sistem kompetisi, di mana keberhasilan individu diorientasikan pada kegagalan orang lain. Model cooperative learning ini dikembangkan untuk mencapai tiga tujuan pembelajaran penting. Ketiga tujuan pembelajaran tersebut adalah sebagai berikut: ${ }^{45}$ pertama, Hasil Belajar Akademik. Meskipun pembelajaran kooperatif ini mencakup beragam tujuan sosial serta memperbaiki prestasi siswa atau tugas-tugas akademis penting lainnya. Beberapa penelitian dari cooperative learning, Johnson, Slavin dan Kagan membuktikan bahwa model ini lebih unggul dalam membantu peserta didik dalam memahami konsep-konsep yang sulit dan dapat meningkatkan nilai (prestasi) peserta didik pada belajar akademik. Cooperative learning memberi keuntungan baik pada siswa

44 Anita Lie, Cooperative Learning: Mempraktikkan Cooperative Learning di Ruang-Ruang Kelas (Jakarta: Grasindo, 2007).

45 Muhammad Fathurrohman, Model-Model Pembelajaran Inovatif.., 48. 
kelompok bawah maupun kelompok atas yang bekerja sama menyelesaikan tugastugas akademik. ${ }^{46}$

Kedua, Penerimaan terhadap perbedaan individu. Model cooperative learning adalah penerimaan secara luas dari orang-orang yang berbeda berdasarkan ras, budaya, kelas sosial, kemampuan dan ketidakmampuannya. Cooperative learning memberi peluang bagi peserta didik dari berbagai latar belakang dan kondisi untuk bekerja dengan saling bergantung pada tugas akademik dan melalui penghargaan kooperatif siswa akan belajar menghargai satu sama lain. ${ }^{47}$ Ketiga, Pengembangan keterampilan sosial. Tujuan ketiga adalah mengajarkan kepada siswa keterampilan bekerja sama dan kolaborasi. Keterampilan keterampilan sosial penting dimiliki oleh siswa sebagai bekal untuk hidup dalam lingkungan sosialnya. ${ }^{48}$

\section{Unsur-Unsur Cooperative Learning}

Pembelajaran kooperatif memiliki unsur-unsur yang saling terkait antara yang satu dengan yang lainnya sebagai berikut: ${ }^{49}$ pertama, Saling Ketergantungan Positif (positive interdependence). Ketergantungan positif ini bukan berarti peserta didik bergantung secara menyeluruh kepada peserta didik lainnya. Jika mereka mengandalkan teman lain tanpa dirinya memberi ataupun menjadi tempat bergantungnya bagi sesamanya, hal itu tidak bisa dinamakan ketergantungan positif. Guru harus menciptakan suasana yang mendorong agar siswa merasa saling membutuhkan. Perasaan saling membutuhkan inilah yang dinamakan positive interdependence. Saling ketergantungan tersebut dapat dicapai melalui ketergantungan tujuan, tugas, bahan atau sumber belajar, peran dan hadiah.

Kedua, Akuntabilitas Individual (individual accountability). Cooperative learning menuntut adanya akuntabilitas individual yang mengukur penguasaan bahan belajar tiap kelompok, dan diberi balikan (umpan balik) tentang prestasi belajar anggotaanggotanya sehingga mereka saling mengetahui rekan yang memerlukan bantuan. Berbeda dengan kelompok tradisional, akuntabilitas individual sering diabaikan sehingga tugas-tugas sering dikerjakan oleh sebagian angggota. Cooperative learning, siswa harus bertanggung jawab terhadap tugas yang diemban masing-masing anggota.

Ketiga, Interaksi Promotif (promotive interaction). Interaksi promotif menuntut semua anggota dalam kelompok belajar dapat saling tatap muka. Mereka dapat berdialog tidak hanya dengan guru tetapi juga bersama dengan teman. Interaksi semacam itu memungkinkan peserta didik menjadi sumber belajar bagi sesamanya. Hal ini diperlukan karena mereka sering merasa lebih mudah belajar dari sesamanya dibandingkan dari guru.

46 Miftahul Huda, Cooperative Learning: Metode, Teknik, Struktur dan Model Penerapan (Yogyakarta: Pustaka Pelajar, 2014), 14.

47 Ibrahim, dkk, Pembelajaran Kooperatif (Surabaya: University Press, 2000), 9.

48 Spencer Kagan \& Miguel Kagan, Kagan Cooperative Leraning (San Clementer: Kagan Publishing, 2009), 11.3. Isjoni, Pembelajaran Kooperatif (Yogyakarta: Pustaka Pelajar, 2009).

49 Anita Lie, Cooperative Learning: Mempraktekkan Cooprative Learning di Ruang Kelas, 31. Trianto, Mendesain Model., 60. 
Kempat, Keterampilan Interpersonal dan Kelompok Kecil (interpersonal and small group skill). ${ }^{50}$ Unsur keempat dari cooperative learning adalah dibekali berbagai interpersonal and small group skill yakni kepemimpinan (leadership), membuat keputusan (decision making), membangun kepercayaan (trust building), kemampuan berkomunikasi dan keterampilan manajemen konflik (management conflict skill). Keterampilan interpersonal lain seperti: tenggang rasa, sikap sopan kepada teman, mengkritik ide, berani mempertahankan pikiran logis, tidak mendominasi yang lain, mandiri dan berbagai sifat lain yang bermanfaat dalam menjalin hubungan antarpribadi tidak hanya diasumsikan tetapi secara sengaja diajarkan.

\section{Lingkungan Belajar dan Sistem Pengelolaan Model Cooperative Learning}

Pembelajaran kooperatif bertitik tolak dari pandangan John Dewey dan Herbert Thelan, yang menyatakan pendidikan dalam masyarakat yang demokratis seyogianya mengajarkan proses demokratis secara langsung. Tingkah laku kooperatif dipandang oleh Dewey dan Thelen sebagai dasar demokrasi dan sekolah dipandang sebagai laboratorium untuk mengembangkan tingkah laku demokrasi. ${ }^{51}$

Proses demokrasi dan peran aktif merupakan ciri yang khas dari lingkungan cooperative learning. Pembentukan kelompok, guru menerapkan struktur tingkat tinggi dan guru juga mendefenisikan semua prosedur. Guru meskipun demikian, tidak dibenarkan mengelola tingkah laku siswa dalam kelompok secara ketat dan siswa memiliki ruang dan peluang untuk secara bebas mengendalikan aktivitas-aktivitas didalam kelompoknya. Cooperative learning menjadi sangat efektif jika materi pembelajaran tersedia lengkap dikelas, ruang guru, perpustakaan, ataupun dipusat media. ${ }^{52}$ Cooperative learning dapat berjalan sesuai dengan harapan dan siswa dapat bekerja secara produktif dalam kelompok, maka siswa perlu diajarkan keterampilanketerampilan kooperatif. Keterampilan kooperatif tersebut berfungsi untuk melancarkan peranan hubungan kerja dan tugas. Peranan hubungan kerja dapat dibangun dengan mengembangkan komunikasi antar anggota kelompok sedangkan peranan tugas dapat dilakukan dengan membagi tugas antar anggota kelompok. ${ }^{53}$

\section{Prinsip-prinsip Cooperative Learning}

Terdapat lima prinsip dasar cooperative learning, seperti dijelaskan dibawah ini: ${ }^{54}$ pertama, Prinsip ketergantungan positif (positive interdependence) yaitu dalam cooperative learning, keberhasilan dalam penyelesaian tugas tergantung pada usaha yang dilakukan oleh kelompok tersebut. Keberhasilan kinerja kelompok ditentukan oleh kinerja masing-masing anggota kelompok. Semua anggota dalam kelompok akan merasa saling ketergantungan. Untuk terciptanya kelompok kerja yang efektif, setiap anggota kelompok masing-masing perlu membagi tugas sesuai dengan tujuan kelompoknya. Tugas tersebut tentu saja disesuaikan dengan kemampuan setiap

50 Johson \& Johson, Cooperative in The Classroom..., 34.

51 Ibrahim, dkk, Pembelajaran Kooperatif (Surabaya: University Press, 2000), 9.

52 Trianto, Mendesain Model Progresif: Konsep, Landasan dan Implementasinya pada Kurikulum Tingkat Satuan Pendidikan, 63.

53 Ibid.

54 Rusman, Model-Model Pembelajaran Mengembangkan Profesionalisme Guru., 212. 
anggota kelompok. Inilah hakekat ketergantungan positif artinya tugas kelompok tidak mungkin bisa diselesaikan manakala ada anggota yang tak bisa menyelesaikan tugasnya dan semua ini memerlukan kerja sama yang baik dari masing-masing anggota kelompok. Anggota kelompok yang mempunyai kemampuan lebih, diharapkan mau dan mampu membantu temannya untuk menyelesaikan tugasnya.

Kedua, Tanggung jawab perseorangan (indivudual accountability) yaitu keberhasilan kelompok sangat tergantung dari masing-masing anggota kelompoknya. Setiap anggota kelompok mempunyai tugas dan tanggung jawab yang harus dikerjakan dalam kelompok tersebut. Ketiga, Interaksi tatap muka (face to face promotion interaction) yaitu memberikan kesempatan yang luas kepada setiap anggota kelompok untuk bertatap muka melakukan interaksi dan diskusi untuk saling memberi dan menerima informasi dari anggota kelompok lain. Pembelajaran kooperatif memberi ruang dan kesempatan yang luas kepada setiap anggota kelompok untuk bertatap muka saling memberikan informasi dan membelajarkan. Interaksi tatap muka akan memberikan pengalaman yang berharga kepada setiap anggota kelompok untuk bekerja sama, menghargai setiap perbedaan, memanfaatkan kelebihan masing-masing anggota dan mengisi kekurangan masing-masing. Kelompok belajar kooperatif dibentuk secara heterogen, yang berasal dari budaya, latar belakang sosial dan kemampuan akademik yang berbeda. Perbedaan semacam ini akan menjadi modal utama dalam proses saling memperkaya antara anggota kelompok. 55

Keempat, Partisipasi dan komunikasi (participation communication) yaitu melatih siswa untuk dapat berpartisipasi aktif dan berkomunikasi dalam kegiatan pembelajaran. Kemampuan ini sangat penting sebagai bekal mereka dalam kehidupan di masyarakat kelak. Sebelum melakukan kooperatif, guru perlu membekali siswa dengan kemampuan berkomunikasi. Tidak setiap siswa mempunyai kemampuan berkomunikasi, misalnya kemampuan mendengarkan dan kemampuan berbicara, padahal keberhasilan kelompok ditentukan oleh partisipasi setiap anggotanya. Untuk dapat melakukan partisipasi dan komunikasi, siswa perlu dibekali dengan kemampuan-kemampuan berkomunikasi. Misalnya, cara menyatakan ketidaksetujuan atau cara menyanggah pendapat orang lain secara santun, tidak memojokkan, cara menyampaikan gagasan dan ide-ide yang dianggapnya baik dan berguna. Keterampilan berkomunikasi memang memerlukan waktu. Siswa tak mungkin dapat menguasainya dalam waktu sekejap. Guru perlu terus melatih dan melatih, sampai pada akhirnya setiap siswa memiliki kemampuan untuk menjadi komunikator yang baik. ${ }^{56}$

Kelima, Evaluasi proses kelompok yaitu menjadwalkan waktu khusus bagi kelompok untuk mengevaluasi proses kerja kelompok dan hasil kerja sama mereka agar selanjutnya bisa bekerja sama dengan lebih efektif. Selain lima unsur penting yang terdapat dalam model cooperative learning, model pembelajaran ini juga mengandung prinsip-prinsip yang membedakan dengan model pembelajaran lainnya. Berdasarkan penjelasan diatas, dapat disimpulkan bahwa konsep utama cooperative learning sebagai landasan atau patokan utama bagi setiap kelompok yang

55 Wina Sanjaya, Strategi Pembelajaran Berorientasi Standar Proses Pendidikan, 244.

56 Ibid, 245. 
berkesempatan mencapai kesuksesan berhak mendapatkan perhargaan kelompok. Kesuksesan bagi kelompok yang mendapatkan penghargaan dilihat dari ke lima (5) prinsip cooperative learning yang merupakan suatu kinerja sistem.

\section{Langkah-langkah Cooperative Learning}

Langkah-langkah cooperative learning pada prinsipnya terdiri atas empat tahap yaitu: ${ }^{57}$ pertama, Penjelasan Materi Tahap penjelasan diartikan sebagai proses penyampaian pokok-pokok materi pembelajaran sebelum siswa belajar dalam kelompok. Tujuan dalam tahap ini adalah pemahaman siswa terhadap pokok materi pelajaran. Guru pada tahap ini memberikan gambaran umum tentang materi pelajaran yang harus dikuasai yang selanjutnya siswa akan memperdalam materi dalam pembelajaran kelompok (tim). Guru pada tahap ini dapat menggunakan metode ceremah, curah pendapat dan Tanya jawab bahkan kalau perlu guru dapat mengggunakan domonstrasi. Guru juga dapat menggunakan berbagai media pembelajaran agar proses penyampaian dapat lebih menarik siswa.

Kedua, Belajar dalam Kelompok. Setelah guru menjelaskan gambaran umum tentang pokok-pokok materi pelajaran, selanjutnya siswa diminta untuk belajar pada kelompoknya masing-masing yang telah dibentuk sebelumnya. Manurut Anita Lie, pengelompoknya dalam model cooperative learning bersifat heterogen, artinya kelompok dibentuk berdasarkan perbedaan-perbedaan setiap anggotanya, baik perbedaan gender, latar belakang agama, sosial-ekonomi dan etnis serta perbedaan kemampuan akademis. Kemampuan dalam hal akademis, kelompok pembelajaran biasanya terdiri dari satu orang berkemampuan akademis tinggi, dua orang dengan kemampuan sedang dan satu lainnya dari kelompok kemampuan akademis kurang. Lie menjelaskan beberapa alasan lebih disukainya pengelompokan heterogen. Pertama, kelompok heterogen memberikan kesempatan untuk saling mengajar (peer tutoring) dan saling mendukung. Kedua, kelompok ini meningkatkan relasi dan interaksi antara ras, agama, etnis dan gender.58 Terakhir, kelompok heterogen memudahkan pengelolaan kelas karena dengan adanya satu orang yang berkemampuan akademis tinggi, guru mendapatkan satu asisten untuk setiap orang. Melalui pembelajaran dalam tim siswa didorong untuk melakukan tukar-menukar (sharing) informasi dan pendapat, mendiskusikan permasalahan secara bersama, membandingkan jawaban mereka dan mengoreksi hal-hal yang kurang tepat.

Ketiga, Penilaian. Penilaian dalam model cooperative learning bisa dilakukan dengan tes atau kuis. Tes atau kuis dilakukan baik secara individual maupun secara kelompok. Tes individual nantinya akan memberikan informasi kemampuan setiap siswa dan tes kelompok akan memberikan informasi kamampuan setiap kelompok. Hasil akhir setiap siswa adalah penggabungan keduanya dan dibagi dua. Nilai setiap kelompok memiliki nilai sama dalam kelompoknya. Hal ini disebabkan nilai kelompok adalah nilai bersama dalam kelompoknya yang merupakan hasil kerja sama setiap anggota kelompok.

Keempat, Pengakuan Tim. Pengakuan tim (team recognition) adalah penetapan tim yang dianggap paling menonjol atau tim paling berprestasi untuk kemudian

57 Ibid.

58 Ibid. 
diberikan penghargaan atau hadiah. Pengakuan dan pemberian penghargaan tersebut diharapkan dapat memotivasi tim untuk terus berprestasi dan juga membangkitkan motivasi tim lain untuk lebih mampu meningkatkan prestasi mareka.

Penerapan model pembelajaran kooperatif pada peserta didik berarti sekolah telah melakukan hal-hal berikut: ${ }^{9}$ (1) Mengembangkan dan menggunakan keterampilan kooperatif berpikir kritis dan kerja sama kelompok. (2) Menyuburkan hubungan antarpribadi yang positif di antara siswa yang berasal dari latar belakang yang berbeda. (3) Menerapkan bimbingan oleh teman (peer coaching). (4) Menciptakan lingkungan yang menghargai, menghormati nilai-nilai ilmiah. (5) Membangun sekolah dalam suasana belajar.

\section{Pembahasan}

Penggunaan model cooperative learning dalam pembelajaran adalah model pembelajaran yang mengutamakan kerja sama di antara siswa untuk mencapai tujuan pembelajaran. Pembelajaran ini akan tercipta sebuah interaksi yang lebih luas antara guru dengan siswa, siswa dengan siswa dan siswa dengan guru. Partisipasi belajar seperti ini akan berdampak pada minat belajar siswa. Hal ini dapat digambarkan pada tabel dibawah ini.

Tabel 1:

Penggunaan Model Cooperative Learning untuk Meningkatkan Minat Belajar Siswa dalam Pembelajaran

\begin{tabular}{|l|l|c|c|}
\hline No & \multicolumn{1}{|c|}{ Instrumen } & \multicolumn{1}{|c|}{ Options } \\
\cline { 3 - 4 } & \multicolumn{1}{|c|}{\begin{tabular}{c}
\multicolumn{1}{|c|}{ Ya } \\
Model cooperative learning adalah guru menyampaikan suatu \\
materi, kemudian para siswa tergabung dalam kelompok \\
heterogen (dilihat dari tingkat kemampuan yang berbeda, jenis \\
kelamin, suku) yang terdiri atas 4 atau 5 orang untuk membahas \\
materi sesuai dengan topik yang diberikan oleh guru. Apakah guru \\
pernah menggunakan model cooperative learning dalam proses \\
pembelajaran di kelas?
\end{tabular}} & 26 & 0 \\
\hline 2 & $\begin{array}{l}\text { Apakah anda merasa nyaman mengikuti pembelajaran di kelas } \\
\text { dengan menggunakan model cooperative learning? }\end{array}$ & 23 & 3 \\
\hline 3 & $\begin{array}{l}\text { Apakah penggunaan model cooperative learning di kelas dapat } \\
\text { meningkatkan minat belajar anda? }\end{array}$ & $1900 \%)$ & $(11,53 \%)$ \\
\hline 4 & $\begin{array}{l}\text { Apakah dengan menggunakan model cooperative learning dapat } \\
\text { mempermudah anda untuk bekerja sama dengan teman-teman } \\
\text { dalam kelompok? }\end{array}$ & 23 & 3 \\
\hline
\end{tabular}

59 Fathurrohman, Model-Model Pembelajaran Inovatif, 53. 


\begin{tabular}{|c|c|c|c|}
\hline 5 & $\begin{array}{l}\text { Apakah penggunaan model cooperative learning di kelas membuat } \\
\text { anda dapat mengingat pelajaran yang telah disampaikan? }\end{array}$ & $\begin{array}{c}18 \\
(69,23 \%)\end{array}$ & $\begin{array}{c}8 \\
(30,77 \%)\end{array}$ \\
\hline 6 & $\begin{array}{l}\text { Apakah materi yang disampaikan dengan menggunakan model } \\
\text { cooperative learning dalam pembelajaran dapat anda pahami? }\end{array}$ & $\begin{array}{c}23 \\
(88,46 \%)\end{array}$ & $\begin{array}{c}3 \\
(11,53 \%)\end{array}$ \\
\hline 7 & $\begin{array}{l}\text { Apakah penggunaan model cooperative learning di kelas dalam } \\
\text { pembelajaran kelompok memberikan kesempatan kepada anda } \\
\text { untuk menemukan atau mengaplikasikan ide-ide? }\end{array}$ & $\begin{array}{c}17 \\
(65,38 \%)\end{array}$ & $\begin{array}{c}9 \\
(34,61 \%)\end{array}$ \\
\hline 8 & $\begin{array}{l}\text { Apakah penggunaan model cooperative learning di kelas } \\
\text { meningkatkan rasa ingin tahu dalam diri untuk bertanya dan } \\
\text { bekerja sama dengan baik bersama teman-teman? }\end{array}$ & $\begin{array}{c}24 \\
(92,30 \%)\end{array}$ & $\begin{array}{c}2 \\
(7,70 \%)\end{array}$ \\
\hline 9 & $\begin{array}{l}\text { Apakah sebelum penggunaan model cooperative learning dimulai } \\
\text { dalam pembelajaran anda mempersiapkan diri dengan baik untuk } \\
\text { mencari dan menggali informasi dari sumber buku mata } \\
\text { pelajaran? }\end{array}$ & $\begin{array}{c}21 \\
(80,74 \%)\end{array}$ & $\begin{array}{c}5 \\
(19,23 \%)\end{array}$ \\
\hline 10 & $\begin{array}{l}\text { Apakah adanya presentasi dari setiap kelompok membuat anda } \\
\text { lebih aktif dalam proses pembelajaran? }\end{array}$ & $\begin{array}{c}18 \\
(69,23 \%)\end{array}$ & $\begin{array}{c}8 \\
(30,77 \%)\end{array}$ \\
\hline 11 & $\begin{array}{l}\text { Apakah adanya diskusi kelompok membuat anda dapat } \\
\text { memperoleh pengalaman baru? }\end{array}$ & $\begin{array}{c}16 \\
(61,53 \%)\end{array}$ & $\begin{array}{c}10 \\
(38,46 \%)\end{array}$ \\
\hline 12 & $\begin{array}{l}\text { Apakah adanya presentasi dari setiap kelompok, anda dapat } \\
\text { menanyakan langsung apabila mengalami kesulitan pada materi } \\
\text { yang telah dijelaskan? }\end{array}$ & $\begin{array}{c}21 \\
(80,74 \%)\end{array}$ & $\begin{array}{c}5 \\
(19,23 \%)\end{array}$ \\
\hline 13 & $\begin{array}{l}\text { Apakah adanya penghargaan yang diberikan oleh guru kepada } \\
\text { kelompok, anda lebih termotivasi dalam mengikuti } \\
\text { pembelajaran? }\end{array}$ & $\begin{array}{c}22 \\
(84,61 \%)\end{array}$ & $\begin{array}{c}4 \\
(15,38 \%)\end{array}$ \\
\hline 14 & $\begin{array}{l}\text { Apakah dengan adanya diskusi kelompok, anda lebih muda } \\
\text { membandingkan jawaban dan mengoreksi jawaban yang kurang } \\
\text { tepat? }\end{array}$ & $\begin{array}{c}17 \\
(65,38 \%)\end{array}$ & $\begin{array}{c}9 \\
(34,61 \%)\end{array}$ \\
\hline 15 & $\begin{array}{l}\text { Apakah diskusi kelompok membuat anda lebih mudah } \\
\text { mengerjakan tugas yang diberikan oleh guru? }\end{array}$ & $\begin{array}{c}20 \\
(76,93 \%)\end{array}$ & $\begin{array}{c}6 \\
(23,07 \%)\end{array}$ \\
\hline
\end{tabular}

Sumber: data olahan hasil angket yang telah disebarkan

Berdasarkan paparan penelitian pada tabel 1 di atas menyatakan penggunaan model cooperative learning untuk meningkatkan minat belajar siswa dalam pembelajaran di kelas dan penulis menjelaskannya dalam setiap item sebagai berikut: 
pertama, dari data yang diperoleh pada item pertama, dapat dirumuskan bahwa guru pernah menggunakan model cooperative learning dalam proses pembelajaran di kelas adalah sebanyak $26(100 \%)$ responden. Kedua, dari data yang diperoleh pada item kedua, dapat dirumuskan bahwa siswa merasa nyaman mengikuti pembelajaran di kelas dengan menggunakan model cooperative learning adalah sebanyak 23 (88,46\%) responden menjawab ya dan $3(11,53 \%)$ responden menjawab tidak. Ketiga, dari data yang diperoleh pada item ketiga, dapat dirumuskan bahwa penggunaan model cooperative learning di kelas dapat meningkatkan minat belajar siswa adalah sebanyak $19(73,07 \%)$ responden menjawab ya dan 7 (26,93\%) responden menjawab tidak.

Keempat, dari data yang diperoleh pada item keempat, dapat dirumuskan bahwa penggunaan model cooperative learning dapat mempermudah peserta didik untuk bekerja sama dengan teman-teman dalam kelompok adalah sebanyak 23 $(88,46 \%)$ responden menjawab ya dan $3(11,53 \%)$ responden menjawab tidak. Kelima, dari data pada item kelima, dapat dirumuskan bahwa penggunaan model cooperative learning di kelas membuat peserta didik dapat mengingat pelajaran yang telah disampaikan dan jawaban yang diberikan oleh responden adalah sebanyak 18 $(69,23 \%)$ responden menjawab ya dan $8(30,77 \%)$ responden menjawab tidak. Keenam, dari data pada item keenam, dapat dirumuskan bahwa materi yang disampaikan dengan menggunakan model cooperative learning dalam pembelajaran dapat dipahami oleh peserta didik dan jawaban yang diberikan responden adalah sebanyak 23 $(88,46 \%)$ responden menjawab ya dan $3(11,53 \%)$ responden menjawab tidak. Ketujuh, dari data pada item ketujuh, dapat dirumuskan bahwa penggunaan model cooperative learning di kelas dalam pembelajaran kelompok memberikan kesempatan kepada siswa untuk menemukan atau mengaplikasikan ide-ide adalah sebanyak 17 (65,38\%) responden menjawab ya dan $9(34,61 \%)$ responden menjawab tidak. Kedelapan, dari data pada item kedelapan, dapat dirumuskan bahwa penggunaan model cooperative learning di kelas meningkatkan rasa ingin tahu dalam diri responden untuk bertanya dan bekerja sama dengan baik bersama teman-teman adalah sebanyak 24 (92,30\%) responden menjawab ya dan $2(7,70 \%)$ responden menjawab tidak.

Kesembilan, dari data pada item kesembilan, dapat dirumuskan bahwa sebelum penggunaan model cooperative learning dimulai dalam pembelajaran siswa telah mempersiapkan diri dengan baik untuk mencari dan menggali informasi dari sumber buku mata pelajaran adalah sebanyak $21(80,74 \%)$ responden menjawab ya dan 5 (19,23\%) responden menjawab tidak. Kesepuluh, dari data pada item kesepuluh, dapat dirumuskan bahwa adanya presentasi dari setiap kelompok membuat anda lebih aktif dalam proses pembelajaran adalah sebanyak $18(69,23 \%)$ responden menjawab ya dan $8(30,77 \%)$ responden menjawab tidak. Kesebelas, dari data pada item kesebelas, dapat dirumuskan bahwa diskusi kelompok membuat peserta didik dapat memperoleh pengalaman baru adalah sebanyak 16 (61,53\%) responden menjawab ya dan $10(38,46 \%)$ responden menjawab tidak. Keduabelas, dari data pada item keduabelas, dapat dirumuskan bahwa dengan adanya presentasi dari setiap kelompok peserta didik dapat menanyakan langsung apabila mengalami kesulitan pada materi yang telah dijelaskan adalah sebanyak $21(80,74 \%)$ responden menjawab ya dan $5(19,23 \%)$ responden menjwaba tidak. Ketigabelas, dari data pada item ketigabelas, dapat dirumuskan bahwa dengan adanya penghargaan yang diberikan 
oleh guru kepada kelompok peserta diidik lebih termotivasi dalam mengikuti pembelajaran adalah sebanyak $22(84,61 \%)$ responden menjawab ya dan $4(15,38 \%)$ responden menjawab tidak.

Keempatbelas, dari data pada item keempatbelas, dapat dirumuskan bahwa diskusi kelompok membuat peserta didik lebih muda membandingkan jawaban dan mengoreksi jawaban yang kurang tepat adalah sebanyak 17 (65,38\%) responden menjawab ya dan $9(34,61 \%)$ responden menjawab tidak. Kelimabelas, dari data pada item kelimabelas, dapat dirumuskan bahwa diskusi kelompok membuat anda lebih mudah mengerjakan tugas yang diberikan oleh guru adalah sebanyak 20 (76,93\%) responden menjawab ya dan $6(23,07 \%)$ responden menjawab tidak.

Berdasarkan jawaban yang diterima peneliti mengenai penggunaan model cooperative learning untuk meningkatkan minat belajar siswa dalam pembelajaran. Peneliti menemukan bahwa model cooperative learning dalam pembelajaran memberikan pengaruh yang positif bagi peserta didik yakni peserta didik merasa nyaman mengikuti pembelajaran, memampukan peserta didik untuk bekerja sama dengan teman-teman melalui diskusi kelompok dan peserta didik dapat memahami materi yang disampaikan sebanyak $23(88,46 \%)$ responden yang menyatakan ya dan $3(11,53 \%)$ responden menyatakan tidak.

Selain itu pembelajaran model cooperative learning juga memampukan peserta didik lebih termotivasi dalam mengikuti pembelajaran sebanyak 22 (84,61\%) responden, peserta didik mempersiapkan diri dengan baik untuk mencari dan menggali informasi dari sumber buku mata pelajaran, adanya presentasi kelompok memotivasi mereka dapat menanyakan langsung apabila mengalami kesulitan pada materi yang telah dijelaskan sebanyak 21 (80,74\%) dan diskusi kelompok membuat siswa-siswi lebih mudah mengerjakan tugas yang diberikan oleh guru sebanyak 20 (76,93\%) responden.

Peserta didik yang berminat mengikuti pembelajaran sebanyak 19 (73,07\%) responden, peserta didik mengingat materi yang disampaikan sebanyak 18 (69,23\%) responden, memberikan kesempatan kepada peserta didik untuk menemukan atau mengaplikasikan ide-ide dan adanya diskusi kelompok peserta didik mudah membandingkan dan mengoreksi jawaban yang kurang tepat sebanyak 17 (65,38\%) responden serta adanya diskusi kelompok membuat peserta didik memperoleh pengalaman baru sebanyak $17(65,38 \%)$ responden. Dengan demikian model cooperative learning memberikan dampak yang baik bagi siswa untuk meningkatkan minat belajar untuk mencapai tujuan pembelajaran yang baik dan sesuai dengan tujuan kompetensi yang diharapkan dalam dunia pendidikan.

\section{Kesimpulan}

Berdasarkan hasil analisa penelitian yang dilakukan di SMAN 1 tentang penggunaan model cooperative learning pada mata pelajaran Pendidikan Agama Kristen (PAK) untuk meningkatkan minat belajar siswa kelas XI IPS 3 SMAN 1 Kupang, jawaban yang diterima penulis dari 27 responden yakni 26 orang siswa-siswi dan 1 orang guru PAK maka penulis menyimpulkan bahwa pembelajaran di kelas terhadap pengaruh penggunaan model cooperative learning untuk meningkatkan minat belajar siswa kelas XI IPS 3 SMAN 1 Kupang. Karena adanya respon yang positif dari 
peserta didik saat pembelajaran di kelas yang di sampaikan dengan menggunakan model cooperative learning, maka penulis memberikan beberapa kesimpulan yaitu: pertama, siswa merasa nyaman dan senang mengikuti pembelajaran dengan menggunakan model cooperative learning. Melalui model cooperative learning ini memberikan kesempatan kepada siswa-siswi untuk menemukan atau mengaplikasikan ide-ide mereka sendiri dalam pembelajaran kelompok. Kedua, adanya perhatian dari siswa ketika materi pelajaran disampaikan menggunakan model cooperative learning sebagai pendukung untuk memotivasi siswa agar berminat dalam kegiatan pembelajaran. Motivasi peserta didik yang ditunjukan dalam pembelajaran yakni teman yang memiliki kemampuan tingkat akademik yang tinggi menjadi sumber belajar bagi peserta didik yang memiliki tingkat kemampuan ratarata, sehingga rasa ingin tahu dari siswa siswi untuk antusias mencari dan menggali informasi dalam menyelesaikan topik atau materi yang akan dibahas. Ketiga, siswa begitu tertarik mengikuti pembelajaran dengan menggunakan model cooperative learning karena mereka mendapat tugas dan kesempatan untuk menjadi ketua (pemimpin) bagi teman-teman dalam kelompok. Tugas dan kepercayaan ini mengajarkan peserta didik untuk menjadi teladan bagi teman-teman yang lain dalam tim. Keempat, siswa mampu mengingat materi yang telah disampaikan melalui model cooperative learning karena dalam pembelajaran kelompok mereka saling membantu menemukan materi yang dibahas secara bersama-sama dan adanya interaksi yang baik antara guru dan peserta didik sebagai sumber belajar. Kelima, siswa dapat memahami materi pelajaran yang disampaikan melalui model cooperative learning. Keenam, bertumbuhnya minat belajar siswa ketika materi pembelajaran disampaikan menggunakan model cooperative learning.

\section{Rujukan}

Bahruddin dan Esa Nur Wahyuni. Teori Belajar \& Pembelajaran. Jogjakarta: Ar-Ruzz Media, 2007.

Daryanto. Penelitian Tindakan Kelas dan Penelitian Tindakan Sekolah. Yogyakarta: Gava Media, 2011.

Dimyati dan Mudjono. Belajar dan Pembelajaran. Jakarta: Rineka Cipta, 2006.

Fathurrohman, Muhammad. Model-model Pembelajaran Inovatif: Alternatif Desain Pembelajaran yang Menyenangkan. Jogjakarta: Ar-Ruzz Media, 2015.

Gillies, Robbin M. et.all. The Teacher's Role in Implementing Cooperative Learning in The Classroom. New York: Springer, 2008.

Gillies, Robbin M., et.all. The Teacher's Role in Implementing Cooperative Learning in The Classroom. New York: Springer, 2008.

Gutek, Gerald L. Historical and Philosophical Foundations of Education: A Biographical Introduction. Upper Saddle River, NJ: Person Education Inc, 2000.

Huda, Miftahul. Cooperative Learning: Metode, Teknik, Struktur dan Model Penerapan. Yogyakarta: Pustaka Pelajar, 2014.

Huda, Miftahul. Cooperative Learning: Metode, Teknik, Struktur dan Model Penerapan. Yogyakarta: Pustaka Pelajar, 2014.

Ibrahim., dkk,. Pembelajaran Kooperati.f Surabaya: University Press, 2000.

Isjoni. Pembelajaran Kooperatif. Yogyakarta: Pustaka Pelajar, 2009. 
Johson, D.W. \& R.T. Johson. Cooperation in The Classroom. USA: Interaction Book Company, 1998.

Jollife, Wendy. Cooperative Learning in The Classroom: Putting it into Practice. California: Paul Chapman Publisihing, 2007.

Joyce, Bruce and Marsha Weil. Models of Teaching. Boston: Allyn and Bacon, 2009.

Kagan, Spencer \& Miguel Kagan. Kagan Cooperative Leraning. San Clementer: Kagan Publishing, 2009.

Kagan, Spencer dan Miguel Kagan. Kagan Cooperative Leraning. San Clementer: Kagan Publishing, 2009.

Komaruddin. Kamus Istilah Karya Tulis Ilmiah. Jakarta: Bumi Aksara, 2000.

Lie, Anita. Cooperative Learning: Mempraktikkan Cooperative Learning di Ruang-Ruang Kelas. Jakarta: Grasindo, 2007.

Nuurulhayati, Siti. Pembelajaran Kooperatif yang Menggairahkan. Jakarta: Wahana, 2002.

Nuurulhayati, Siti. Pembelajaran Kooperatif yang Menggairahkan. Jakarta: Wahana, 2002.

Pusat Bahasa Departemen Pendidikan Nasional. Kamus Besar Bahasa Indonesia. (Jakarta: Balai Pustaka: 2007.

Sagala, Syaiful. Supervisi Pembelajaran Dalam Profesi Pendidikan: Membantu Mengatasi Kesulitan Guru Memberikan Layanan Belajar yang Bermutu. Bandung: Alfabeta, 2010.

Sanjaya, Wina. Strategi Pembelajaran: Berorientasi Standar Proses Pendidikan. Jakarta: Kencana Prenada Media Group, 2006.

Sidjabat, B. S. Mengajar secara Profeionalsime. Bandung: Yayasan Kalam Hidup, 2011.

Slavin, Robert E. Cooperative Learning: Teori, Riset dan Praktik. Bandung: Nusa Media, 2009.

Trianto. Mendesain Model Progresif: Konsep, Landasan dan Implementasinya pada Kurikulum Tingkat Satuan Pendidikan. Jakarta: Kencana Prenada Media, 2009. 